\title{
Examining the relationship between patent applications and financial positions in the upstream Oil and Gas Industry: evidence from Brazil
}

\author{
Fábio O. Paula \\ fabioop@iag.puc-rio.br | IAG Business School, Pontifical Catholic University of Rio de Janeiro \\ Gabriel M. Cavalheiro \\ gabrielmarcuzzo@id.uff.br | Universidade Federal Fluminense
}

\begin{abstract}
With the discovery of the Pre-Salt reserves, exploration of oil and gas has been strongly extended in Brazil, contributing to the recent increase in the demand for drilling capabilities. This paper discusses the impact of this oil discovery by assessing the relationship among the growth of proven reserves, firms' financial position, and patent applications in the Brazilian upstream oil and gas industry. We provide empirical evidence that the growth of proven oil reserves stimulates firms to apply for patents. The results also indicated that organizations with higher financial performance were more aggressive in increasing the number of patent filings addressing the upstream oil and gas domain technologies.
\end{abstract}

Keywords. Patent; Innovation; Oil Industry; Performance Measurement.

Cite paper as: Paula, F.O., Cavalheiro, G.M., (2020). Examining the relationship between patent applications and financial positions in the upstream Oil and Gas Industry: evidence from Brazil, Journal of Innovation Management, www.open-jim.org, 8(4), 78-102. 


\section{Introduction}

The oil and gas industry is essential for today's economy as oil is still the primary source of energy and one of the main commodities (Coleman, 2012; Fraune \& Knodt, 2018; Wenrui et al., 2013). Relying on this global importance, many countries from different parts of the world have oil and gas industry as the most or one of the most important for their economies, such as the Arabic countries, Russia, Angola, Brazil, Venezuela, and Norway (US Energy Information Administration, 2018). Although the industry is nearly lucrative, the prices are very dependent on global political and economic conditions by being its product a commodity. For example, the barrel of oil from 2014 to 2018 peaked at $\$ 107.95$ in 2014 and dropped to its lower level in 2016, just $\$ 26.21$ (Macrotrends, 2019). This volatility of prices and the high cost of exploration in some environments, such as in the Brazilian pre-salt, in which oil is extracted from up to 7,000 meters deep in the sea (Nunes \& Luna, 2017), make the companies always research new production techniques to reduce costs, which demands high levels of process innovation (Moutinho et al., 2015). Besides, keeping a stable level of reserves is seen as strategic by many countries, requiring strong efforts to identify new and unexplored reserves (Shafiee \& Topal, 2009), which is associated with the constant development of new exploration techniques (Hayashi et al., 2010), also relying on innovativeness. This context is reflected by the high patent applications level by both oil and gas companies and suppliers. For instance, according to Patentscope (WIPO, 2018a), patent applications on the technical area E21B, under which technologies for oil and gas exploration are classified, amounted 38.588 from 2009 to 2018 only in the US.

In Brazil, the E21B technical area started to become a technological hotspot in 2007, resulting primarily from the increase in the number of patents filed by US oil service providers, rather than operating companies (Cavalheiro, Joia, \& Gonçalves, 2014). In this year, it was announced the discovery by Petróleo Brasileiro S.A. (Petrobras) of the pre-salt oil reserve, one of the largest found recently globally (Haddad \& Giuberti, 2010), generating the expectation to make Brazil as one of the biggest oil-producing countries in the world (Cavalheiro, 2016). These expectations are supported by the large amount of proven reserves, which were 12.8 billion barrels by the end of 2017, and by the amount of oil explored, which in 2017 reached around 2.7 million barrels per day (ANP, 2017). These significant numbers were achieved even with the exploration not being conducted in the highest possible speed by the sequence of scandals that targeted Petrobras (Trojbicz \& Loureiro, 2018), and by closed legislation that only in 2016 allowed foreign operating companies to explore pre-salt fields without the participation of the Brazilian oil company (Deutshe Welle, 2016).

By recognizing the increasing importance of Brazil in the global oil and gas industry as a country that started to be included in the family of patent applications covering E21B technologies, and by recognizing that this context could be also similar to other countries that also find important oil reserves in the future, this work investigated some factors that are supposed to stimulate patent applications in this context. Factors related to the protection of knowledge (e.g., Wang et al., 2015), demonstration of technological competences to increase market power (e.g., Neuhäusler, 2011), and market attractiveness (e.g., Stadler, 2011) are among the ones explored in the literature.

Specifically, this study intends to explore the relationship among the growth of proven reserves 
(related to the pre-salt discovery), the financial position of firms, and patent applications. An increase in patent applications indicates the increment of investments in technology and innovation by multinational service or operating companies in the country. It is expected that these relationships should be significantly positive, as the country is becoming a more important player in this global industry. The research also intends to identify factors that may influence firms' interest in applying for patents in Brazil.

The remainder of the paper is composed of a literature review, which presents the two hypotheses tested, followed by the method section, including a description of the data, sample selection, variables, and the statistical method. Then, it presents a discussion of the results and the conclusions, indicating some limitations and highlighting the contribution and policy implications.

\section{Literature review}

\subsection{Patent information}

Considerable uncertainty levels increasingly characterize product innovation, given the difficulties in forecasting product performance, costs, as well as future market demand (Pavitt, 2005). Consequently, the international patent system plays an essential role in supporting innovative firms that invest heavily in developing new technologies. Given the enormous investments associated with the development of new technology-intensive products, innovative firms are highly interested in instruments that can be deployed to protect their investment by minimizing the risk of counterfeiting (Joia, 2000; Paula \& Rocha, 2000; Wang et al., 2015). Accordingly, patents can be defined as legal instruments providing temporary exclusive rights to enable innovative firms operating competitive markets to maximize financial returns from their R\&D investments (Drivas et al., 2016). In this way, Bolívar-Ramos (2017) points out that firms interested in increasing their patenting activities should also spend more on R\&D and joining collaboration networks. In practice, firms protect their investments in developing new technologies by filing patent applications in patent offices of countries in which the domestic market is considered relevant to commercialize the invention (Scherer, 1972; Godinho \& Ferreira, 2012).

In essence, a patent can be considered a formal document that establishes boundaries regarding an invention by publicly identifying a set of protected technical characteristics (Ernst, 2003; Mouritsen \& Koleva, 2005). As such, patents are recognized as the primary instrument to prevent product imitation (Blind et al., 2009). Furthermore, the financial value of patents is subject to a high level of dynamics. In general, the main factors influencing it include the potential for licensing to other businesses (Wang et al., 2015), the size of the market protected by the patent (Fabry et al., 2006), the quality of the patent document (Picard \& van Pottelsberghe, 2011), and the effectiveness of local patent enforcement (Lang, 2001). Typically, as Davies (1997) pointed out, technologies become progressively obsolete, resulting in a reduction of commercial value as time goes by.

Since the number of patent applications has been increasing worldwide in the past three decades, the patent system is characterized by an increasing level of complexity (Bonino et al., 2010). Therefore, at present, it is possible to observe that sophisticated artifacts, such as smartphones 
and tablets, incorporate hundreds or even thousands of patents. As a consequence of patent portfolios' explosive growth, the costs involved in licensing the most important patents are continuously increasing, especially in markets where time-to-market is a significant concern (Galini, 2002).

Provided the intense technological competition generated by World War II, rapid progress could be observed in most technical domains (Castells, 2000). In this way, the international patent system gained critical economic importance following the noted technology advances from World War II. Additionally, since firms operating in technology-intensive sectors rely on patent portfolios to commercialize their products, patent information analysis also became a critical necessity for players in the technology arena.

Besides the rapid growth of available patent documents, information analytics technologies have deeply impacted patent information practice, motivating the development of powerful patent analysis tools. Therefore, at present, sophisticated digital tools were developed to support activities such as formulating technology strategy, detecting patent infringement, determining patent quality, and identifying technological hotspots (Abbas et al., 2014). Moreover, patent information can also be employed for R\&D portfolio management and to monitor competitors (Ernst, 2003). To analyze patent data from heterogeneous, dynamic and scattered data sources, researchers in this realm count on increasingly sophisticated solutions, such as patent landscape, text mining, and digital mind mapping tools to help identify business-relevant patterns in extensive data set (Dirnberger, 2016).

Provided significant advances in patent analytics capabilities in the past few years, patent information can be employed to support various studies involving multiple areas of knowledge. As such, it is possible to recognize the value of examining patent information in different types of analyses. For instance, in the computing industry, it is worth mentioning that patent information supported the study of the evolution of cloud computing technologies (Huang, 2016). Additionally, recent technologies related to wind power can also be evaluated by carrying out prior-art patent searches (Dubaric et al., 2011). Moreover, Lu et al. (2018) examined the relationship between co-patent intensity and the market value of SMEs, along with the moderating effects of the supplier's trade credit and government subsidies. Another relevant example of the consistent analysis of patent information regards assessing universities' patent licensing experience (Drivas et al., 2016). Technology commercialization patterns were also addressed by Sun and Lin (2018). They explored how patent-based measures can inform the likelihood of product commercialization and commercialization speed in the pharmaceutical industry in the US.

Given the increasing importance of patents, reputable scholars have focused on improving understanding of patenting determinants and reasons. In this regard, Karvonen and Klemola (2019) argue that since biofuels can be considered one of the most rapidly growing sectors globally, the IPC codes corresponding to biofuel technologies are also very active. Many authors link patenting with improvements in firm performance (e.g., Alt, 2018; Neuhäusler, 2011; Paula \& Rocha, 2020). In fact, they can be a source of competitive advantage, especially in critical technological areas (Pargaonkar, 2016). Patents are part of successfully innovative firms' outputs and are used to protect them from counterfeiting (Fabry et al., 2006; Joia, 2000; Paula \& Rocha, 2020; Wang et al., 2015). Therefore, as a market becomes more attractive (in Brazil, with growing proven oil 
reserves), more innovative and successful MNEs would be interested in bringing their innovative solutions to compete in this landscape (Stadler, 2011). Grandstrand and Hogersson (2012) also recognize the importance of the demand potential for technology as they point out that the size of the market is an important factor for filing patents, as the numbers of national first filings are declining in small countries like Sweden and Finland, while large companies are increasingly using the PCT route. Also, patents indicate a firm's knowledge stock (DeCarolis \& Deeds, 1999), and demonstrate its technological competitiveness to the market (Freeman, 1982; Huang, 2016; Neuhäusler, 2011), market power, and barriers of entry to new competitors (Fabry et al., 2006). Patents can also be used to support an intentional transfer of technology to other players by disclosing the characteristics of the invention (Siegel et al., 2004). Lastly, patenting firms may also earn money by licensing their solutions (Alt, 2018), which is a practice that was previously observed in the Brazilian Oil and Gas industry (Paula \& Barbosa, 2018).

Considering the firm's characteristics that influence the patent applications, Schneider (2007) provided evidence that the applicant's patenting history, measured by previous applications' stock, is a determinant in this process. Beyond this, the particular characteristics of different industries are also acknowledged. For instance, Choi and Cho (2018) point out that the reasons for renewing patents can vary across industries, given different rates of technological innovation. Also, focusing on the characteristics of an industry, Huang et al. (2011) examined organizational and individual determinants for patent applications by academic scientists in the United States. The authors observed that both the university patent policy and the university technology transfer offices play an essential role in encouraging scientists to file their first patent. Moreover, Bannò (2016) researched the reasons for the patenting of Italian family businesses. This research indicated that the presence of young successors is a positive driver of patent applications.

Following the growth in the use of patent information to support the decision-making of firms, as stated by Galini (2002), policymakers also adopted patent analytics tools to support the formulation of public policy addressing science and technology, as well as assessing patterns of R\&D activities (Godinho \& Ferreira, 2012). Yet, despite the importance of patent information, there is insufficient empirical evidence confirming a direct relationship between patents and innovations and, therefore, patents remain a weak performance indicator for innovation (Boldrin and Levine, 2013).

Although the number of patent applications has been increasing throughout the world in recent decades, a common concern is the geographical concentration of patent applicants. The globalization contributed to strengthening collaboration between researchers in different countries (Nelson, 2007). However, most intellectual property rights (IPRs) belong to entities in developed countries (Lall, 2003).

\subsection{Brazilian context: pre-salt discovery}

Brazil can be considered a country with extensive experience regarding oil discovery and production. The first oil discovery in Brazil was accomplished in 1939, but the first oil production happened decades later in 1968 (Rodriguez \& Suslick, 2009). Although the first oil production occurred in the late sixties, Brazil remained dependent on importing oil from foreign countries 
to meet the domestic demand (Oliveira, 2011). Nevertheless, the discovery of oil reserves located offshore approximately 7,000 meters below the sea level and more than a hundred kilometers from the coast created the prospect of turning the country from oil importing to an oil-exporting country (Haddad \& Giuberti, 2010). This discovery was accomplished in 2007 and created the need for new technologies to explore oil in such adverse conditions (National Petroleum Council, 2007).

According to Alley (2018), becoming an oil-exporting country has important implications for a country's economy, as a single product becomes the primary source of export revenues. Although the discovery was made by Petrobras, a state-owned company, the oil exploration monopoly was abolished in 1997 in Brazil; therefore, the pre-salt reserves are being explored by consortia (Trojbicz \& Loureiro, 2018).

In order to explore this vast oil field, substantial effort is required to develop and integrate innovative technologies to address the highly specific challenges of the largest subsea project in the world, which involves a combination of operating in the ultra-deep-water and long distance from the coast (Oliveira, 2011). Therefore, due to continuous technological advancements, global oil and gas reserves did not decline over the last few decades (Shafiee \& Topal, 2009; Sovacool, 2016). Additionally, the increasing use of renewable energy contributes to providing additional energy supply and motivating discussions regarding energy transitions (Araújo, 2014).

Increasingly, the discovery of new oil reserves creates the necessity of more sophisticated exploration technology (Oliveira, 2011; Sovacool, 2016). However, Brazil is a developing country, and its local service providers in the oil and gas industry face limitations regarding their innovative and patenting capabilities (Bell \& Figueiredo, 2012; Kim, 1997; 1998; Paula \& Rocha, 2020). Typically, national firms usually do not have a high level of capital, resources, and technological capabilities ( $\mathrm{Li}$ et al., 2006; Li, Liu \& Ren, 2007) and operate in a weaker National System of Innovation, with fewer researchers, investments in R\&D and accumulated patents (CuervoCazurra \& Rui, 2017). MNEs with headquarters located in developed countries, in turn, do not face these difficulties, as they usually have the resources and capabilities to develop the technologies in research centers located in the same country as their headquarters and transfer them to any other country (Lall, 2003). As such, some contextual issues are affecting all these players. For instance, the patent system is usually weak in countries such as Brazil, with a costly and time-consuming patenting process (Falce et al., 2019) and little legal protection against counterfeiting (Cuervo-Cazurra \& Rui, 2017), which may discourage firms from filing patent applications (Lang, 2001). Pieces of evidence reinforced this possibility that firms from extractive industries prefer to rely on informal appropriability mechanisms to protect their process innovations than in IPRs (World Bank, 2019).

Even with the cited barriers MNEs and national firms face to file patent applications in developing countries, it is reasonable to assume that a sufficiently large stimulus would make these firms make more efforts in this process. The literature stated that supply and demand factors that transform the market to be more attractive are relevant to promote innovation (Kalcheva et al., 2018). Stadler (2011), for instance, stated that firms incentivize cooperation for innovating and patenting when demand increases in the oil and gas industry (Stadler, 2011). Additionally, MNEs are also looking for opportunities in developing countries, creating alternative strategies 
to deal with the IP protection system's weaknesses in these countries (Nguyen, 2020). One of the policies that incentivized this movement was adopting minimum IP protection standards by many developing countries, including Brazil, which participated in the 1994 Trade-Related Aspects of Intellectual Property Rights (TRIPS) agreement of the World Trade Organization WTO (Brandl et al., 2019). Reinforcing this argument, several authors described an ongoing move of MNEs to emerging markets (e.g., Lema, Quadros, \& Shimitz, 2015; Qi et al., 2014; Ervits, 2020). Specifically, in the Brazilian upstream oil and gas industry, the pre-salt discovery was correlated with an increase in patent applications by MNEs (Cavalheiro, Joia, \& Gonçalves, 2014), indicating that many oil and gas operators and suppliers identified in Brazil an excellent opportunity to grow and improve their financial performances (Haddad \& Giuberti, 2010). Considering the arguments already mentioned, we propose that the growth of proven reserves is an important factor that incentivizes patent applications by national and foreign MNEs in the upstream oil and gas industry.

H1: The application for patents by oil and gas operators and suppliers in the upstream in Brazil is positively related to the growth of proven reserves.

Technologies for the upstream oil and gas industry, a capital-intensive industry, are expensive to develop (Wanasinghe et al., 2020). Therefore, it is reasonable to assume that global firms with a high financial performance would have better conditions to explore the emerging opportunities in the Brazilian oil and gas arena than their competitors with lower financial performance. These opportunities refer primarily to the increased potential for selling services and equipment to oil operators, such as Petrobras, Shell, and Total. Also, the exploration of oil and gas fields is based on long-term contracts (Alley, 2018) and will not provide opportunities for revenues in the short or medium term. Firms with a healthier economic situation would be more able to invest in a long-term opportunity.

However, the influence of current firm performance on innovation efforts (such as patenting) is not a consensus in the extant literature. On the one hand, some papers stated that firms with a higher performance would be more prone to innovate (Levinthal \& March, 1981; Paula \& Silva, 2018). They are in a better condition (i.e., have more money, count on the shareholders' support to invest) to invest in innovation activities, including patents (Paula \& Silva, 2018). On the other hand, some authors advocate that better performance would decrease innovation efforts and innovation performance (Cyert \& March, 1963; Greve, 2003). According to these authors, a financial performance below the expected would stimulate managers to start a "problemistic search" (search for solutions for a problem) that drives to more investments in R\&D (Cyert \& March, 1963; Greve, 2003) and, in consequence, innovation.

Empirical findings in the literature diverge. Yayavaram and Chen (2015), for instance, found a positive influence of past firm performance (ROA) on the patent citation. Greve (2003), in its turn, showed that a high performance reduces $R \& D$ intensity and innovation. Operti and Carnabuci (2014) could not find any influence of ROI on the number of patents granted to a firm weighed by the number of forward citations received by them in five years. Katila and Ahuja (2002) did not find a significant relationship between ROA and the launch of new products. Hagedoorn and Wang (2012) did not find a significant relationship between net income and patents in biotech firms. Even with the contradictory arguments and results presented, we 
hypothesize that the influence of firm financial performance on patent applications concerning the oil and gas upstream technologies is positive, as the following hypothesis states.

H2: The application for patents by oil and gas operators and suppliers in the upstream segment in Brazil is positively related to these firms' financial performance.

\section{Method}

\subsection{Data sources and sample}

In order to test the hypotheses, the empirical analysis contained patent and financial performance data from 21 oil and gas operators and suppliers with operations in the upstream oil and gas industry, and that filed at least ten patents addressing the technical area of E21B in Brazil from 2001 to 2014. Patent data were gathered from the World Intellectual Property Organization (WIPO) database Patentscope (WIPO, 2018a). It consisted of patents filed in Brazil at the National Institute of Intellectual Property (INPI) that were classified in the technical area of E21B (earth or rock drilling; obtaining oil, gas, water) according to the International Patent Classification (IPC). This area covers most technologies associated with upstream oil and gas exploration. As patent applications have 18-month secrecy, only patents filed in 2014 or before were guaranteed to be in the database. Financial performance data were obtained from a Bloomberg terminal (Bloomberg, 2018). Data on reserves and barrels extracted were obtained from reports of the National Oil Agency (ANP, 2017). Panel data were set up with 294 firm-year observations. It should be noticed that there are some firms with no financial data for some years; however, the statistical techniques utilized to run the model are able to treat this type of absence of data in the panel.

\subsection{Variables' description}

The study's dependent variable is the number of patents filed for by a firm in a year: (patents y). The independent variables are the log of proven oil reserves in the previous year - $\ln$ (reserves $y$-1) — which is used to test $\mathrm{H} 1$, and the following financial performance measures to test $\mathrm{H} 2$ : growth rev. - percentage growth of revenues compared to the previous year; $\ln$ (EBITDA, adj.) - $\log$ of the earnings before interest, tax, depreciation, and amortization (EBITDA); margin EBITDA - the ratio of EBITDA and total revenue; ln (net income, adj.) - log of total profits; margin net income - the ratio of total profits and total revenues; return on common equity - the ratio of net income and shareholder's equity; and return on assets - the ratio of net income and total assets.

As control variables, we chose some commonly used in the patent literature. The first one, age, is controlled in most studies (e.g., Clò et al., 2019; Lin et al., 2012; Park, Srivastava, \& Gnyawali, 2014; Rydehell, Isaksson, \& Löfsten, 2019). The firm size as total revenues is also commonly used (e.g., Berry, 2014; Rydehell et al., 2019; Schilling, 2015; Xu, Fenik, \& Shaner, 2014), and in this study, we used the logged variable, ln (revenue, adj.). We also added the number of the same type of patents accumulated in five years, from year 5 to the analyzed year - accumulated 
patents $5 y$, to control for the previous capability to patent and accumulated knowledge in the field (e.g., Buchmann and Kaiser, 2019; Chatterji \& Fabrizio, 2014; Schilling, 2015). Oil \& gas is a categorical variable that is 0 if the firm is a supplier and 1 if it is an oil and gas operator, to control the industry (e.g., Arora, Athreye, \& Huang, 2016; Hagedoorn \& Wang, 2012; Schilling, 2015). Lastly, we controlled by the logged number of barriers extracted in the previous year - ln (barrels $y-1)$, as we consider that this number can indicate the market relevance and influence firms to patent more as they enter or dedicate more intensely to explore oil in Brazil. Commonly used control variables, such as R\&D intensity and the number of employees, were not available.

\subsection{About the Layout and Style}

We tested four models for the estimation, two panel negative binomial regression models, and two panel Poisson regression models, both with fixed effects (see the results in Table 3). These two estimation techniques are the most commonly used in the literature when patent count is the dependent variable, as they are appropriate for estimating counting variables. Some studies that used negative binomial regression are Bronzini and Piselli (2016), Buchmann and Kaiser (201), Hagedoorn and Wang (2012), Part et al. (2014), and Schilling and Phelps (2007). Examples of papers that used Poisson regression are less common (e.g., Aharonson, Baum, \& Plunket, 2008; Clò et al., 2020; Xu, Fenik \& Shaner, 2014). A negative binomial is preferable compared to a Poisson model because the variance of the dependent variable in this paper (see Table 1) exceeds the average considerably (Miaou, 1994). And a fixed-effects model is better than a randomeffects model when omitted variables correlate with the model's variables (Allison, 2009), and we cannot guarantee otherwise. As such, we kept the Poisson model with fixed-effects as a robustness check. Model 1 in both methods contained only the control variables. Model 2 tested hypothesis 1 by introducing the variable $\ln$ (Reserves $\mathrm{y}-1$ ) and hypothesis 2 by introducing the proxies of financial performance. The full equation tested (Model 2) is below:

$[$ Patents $\mathrm{y}]=\beta \mathrm{a} 0+\beta \mathrm{a} 1 * \ln ($ reserves $\mathrm{y}-1)+\beta \mathrm{a} 2 *$ growth rev. $+\beta \mathrm{a} 3 * \ln$

$($ EBITDA, adj. $)+\beta \mathrm{a} 4 *$ margin EBITDA $+\beta \mathrm{a} 5 * \ln ($ net income, adj. $)+$

$\beta \mathrm{a} 6 *$ margin net income $+\beta \mathrm{a} 7^{*}$ return on common equity $+\beta \mathrm{a} 8{ }^{*}$ return on assets

$+\beta \mathrm{a} 9 *$ age $+\beta \mathrm{a} 10 * \ln ($ revenue, adj. $)+\beta$ a11*accumulated patents $5 \mathrm{y}+\beta \mathrm{a} 12^{*}$ oil

$$
\& \text { gas }+\beta \text { a } 13^{*} \ln (\text { barrels } \mathrm{y}-1)+\mathcal{E}
$$

\section{Results}

Table 1 shows the sample's descriptive statistics and the two types of firms (operators and suppliers) from 2001 to 2014. As we have panel data, the descriptive statistics calculated the average and standard deviation of all variables for the whole period. The exceptions were the variables barrels and reserves, which varies only by the year. The ANOVA indicated that oil and gas operators consistently had a higher financial performance. All proxies, except for growth rev. and margin net income, were higher for this type of firm. Oil and gas operators also apply more for patents (5.11 patent applications per year versus 3.03 of the suppliers) and have more accumulated patents in five years (27.38 versus 15.96$)$. 
Table 1. Descriptive statistics

\begin{tabular}{|c|c|c|c|c|c|c|}
\hline & \multirow{2}{*}{\multicolumn{2}{|c|}{$\begin{array}{c}\text { All firms } \\
(n=21)\end{array}$}} & \multirow{2}{*}{\multicolumn{2}{|c|}{$\begin{array}{c}\text { Operators } \\
(\mathbf{n}=\mathbf{5})\end{array}$}} & \multirow{2}{*}{\multicolumn{2}{|c|}{$\begin{array}{c}\text { Suppliers } \\
(\mathrm{n}=16)\end{array}$}} \\
\hline & & & & & & \\
\hline Variable & Avg. & Std.Dev. & Avg. & Std.Dev. & Avg. & Std.Dev. \\
\hline age $* * *$ & 102.5 & 75.4 & 144,1 & 130,2 & 89,5 & 38,9 \\
\hline $\begin{array}{l}\text { revenue, adj }(\mathrm{U} \$ \\
1,000)^{* * *}\end{array}$ & 52,893 & 101,782 & 172,814 & 148,859 & 13,499 & 16,301 \\
\hline growth rev. & $13.85 \%$ & 0.21 & 0.11 & 0.20 & 0.15 & 0.21 \\
\hline $\begin{array}{l}\text { EBITDA, adj. (U\$ } \\
1,000)^{* * *}\end{array}$ & 9,677 & 15,834 & 30,217 & 19,654 & 2,863 & 4,489 \\
\hline $\begin{array}{l}\text { net income, adj. (U\$ } \\
1,000)^{* * *}\end{array}$ & 4,611 & 8,604 & 14,637 & 12,179 & 1,318 & 2,480 \\
\hline margin EBITDA*** & 0.18 & 0.10 & 0.22 & 0.12 & 0.17 & 0.09 \\
\hline margin net income & 0.09 & 0.14 & 0.10 & 0.08 & 0.08 & 0.15 \\
\hline $\begin{array}{l}\text { return on common } \\
\text { equity*** }\end{array}$ & 0.15 & 0.15 & 0.21 & 0.12 & 0.14 & 0.16 \\
\hline return on assets $* *$ & 0.07 & 0.06 & 0.08 & 0.05 & 0.06 & 0.07 \\
\hline patents $\mathrm{y}^{* *}$ & 3.53 & 6.74 & 5.11 & 7.48 & 3.03 & 6.44 \\
\hline accum patents $5 \mathrm{y}^{* *}$ & 18.68 & 29.35 & 27.38 & 29.19 & 15.96 & 28.95 \\
\hline barrels $\left(10^{4}\right)$ & 6,544 & 1,032 & - & - & - & - \\
\hline reserves $\left(10^{6}\right.$ barrels $)$ & 11,866 & 2,228 & - & - & - & - \\
\hline
\end{tabular}

** $p<0.05$; *** $p<0.01$, indicating significant average differences between Operators and Suppliers

The 21 firms included in the sample filed at INPI 1,044 patents in the technical area E21B in the period considered in the research (2001-2014) from a total of 7,854 (representing 13.29\%). Not all patents in this classification are associated with upstream oil and gas exploration, as E21B patents are related not only to this sector but to earth and rock drilling to extract oil, gas, water, and other soluble or meltable materials (WIPO, 2018b). As the sample firms are only oil and gas operators or suppliers, the tendency is that the 1,044 patents represent a much higher proportion of all patents related directly to oil and gas extraction.

Figure 1 compares patents filed by oil and gas operators with patents filed by suppliers. In our sample, there are only five oil and gas operators (23.80\% of the sample) responsible for the filing of 357 patents ( $34.20 \%$ of the total). The 16 suppliers filed 687 patents in the period, which represents $65.80 \%$. The growth tendency is similar for both groups in the period. There is a growth from 2001 to 2005, followed by a decline from 2006 to 2010 (the exception is 2007 for the suppliers). After 2010, there was a fast recovery in 2011, followed by another decline in 2012. After 2012, another recovery may be observed, with growth until the end of the period analyzed. 


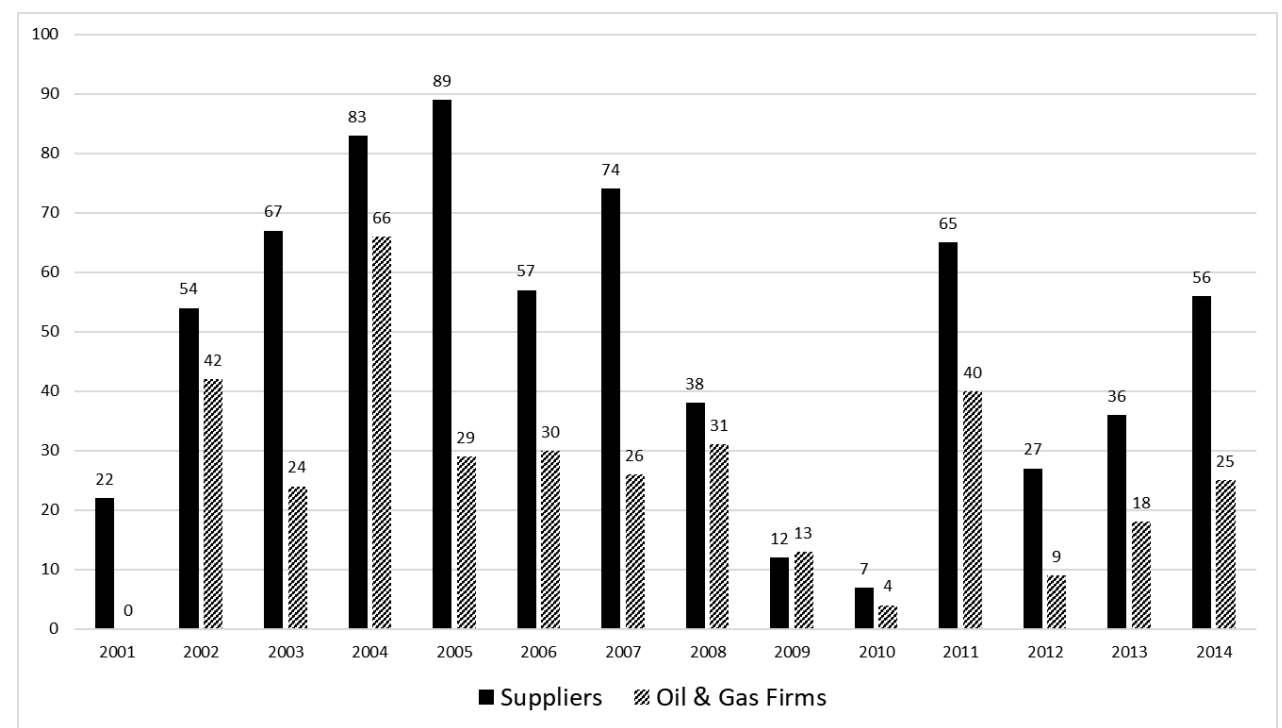

Fig. 1. Patents per year - Oil \& Gas Operators and Suppliers

Figure 2 shows the evolution of barrels extracted and total reserves (in barrels) from 2000 to 2014 in Brazil (as the model uses barrels and reserves from the previous year compared to the patents, we included the year of 2000 in this chart). The figure shows that both variables consistently grow over the years. From 2000 to 2014, the numbers almost doubled. Barrels extracted grew from around 450 million in 2000 to more than 820 million in 2014. Similarly, the reserves rose from nearly eight billion barres in 2000 to more than 15 billion barrels in 2014 .

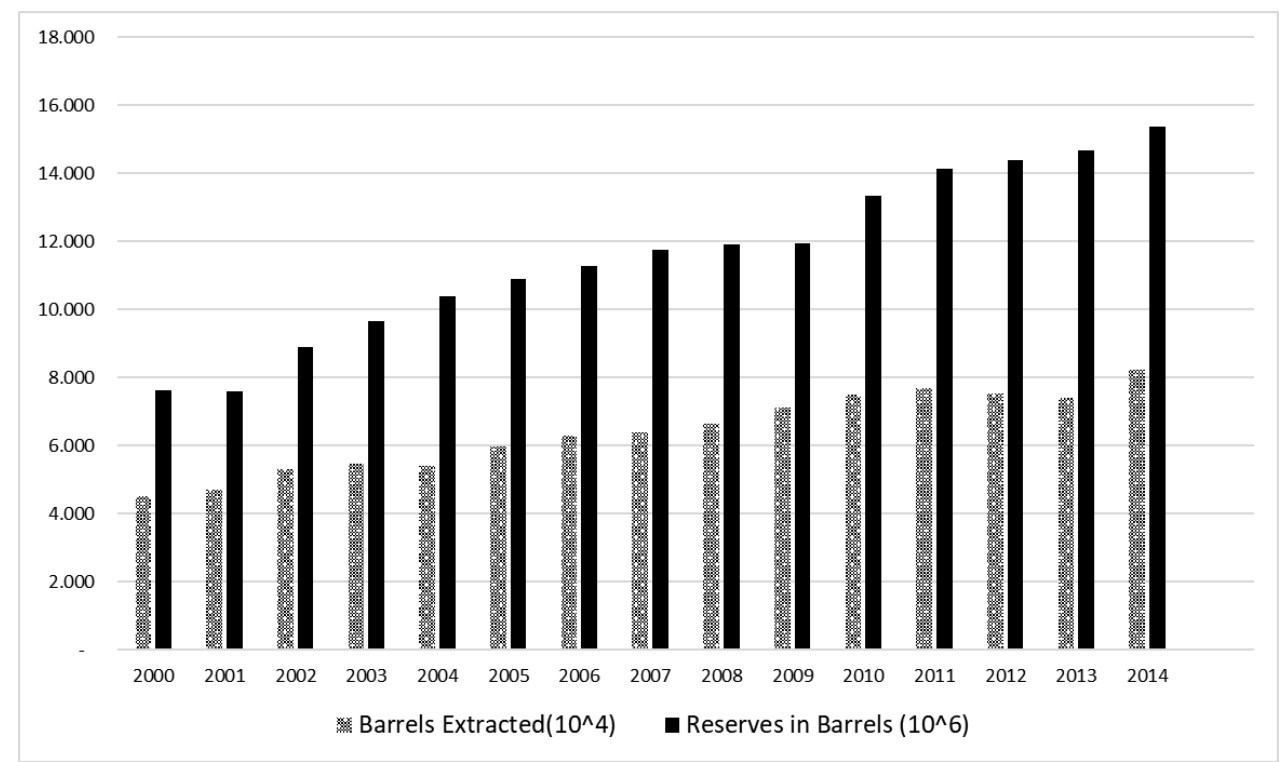

Fig. 2. Barrels extracted and reserves (in barrels) per year in Brazil

Following the analysis, we present the Pearson's correlation table (see Table 2) of the variables used in the model. Most present average correlations, between 0.1 and 0.5$)$. However, it shows 


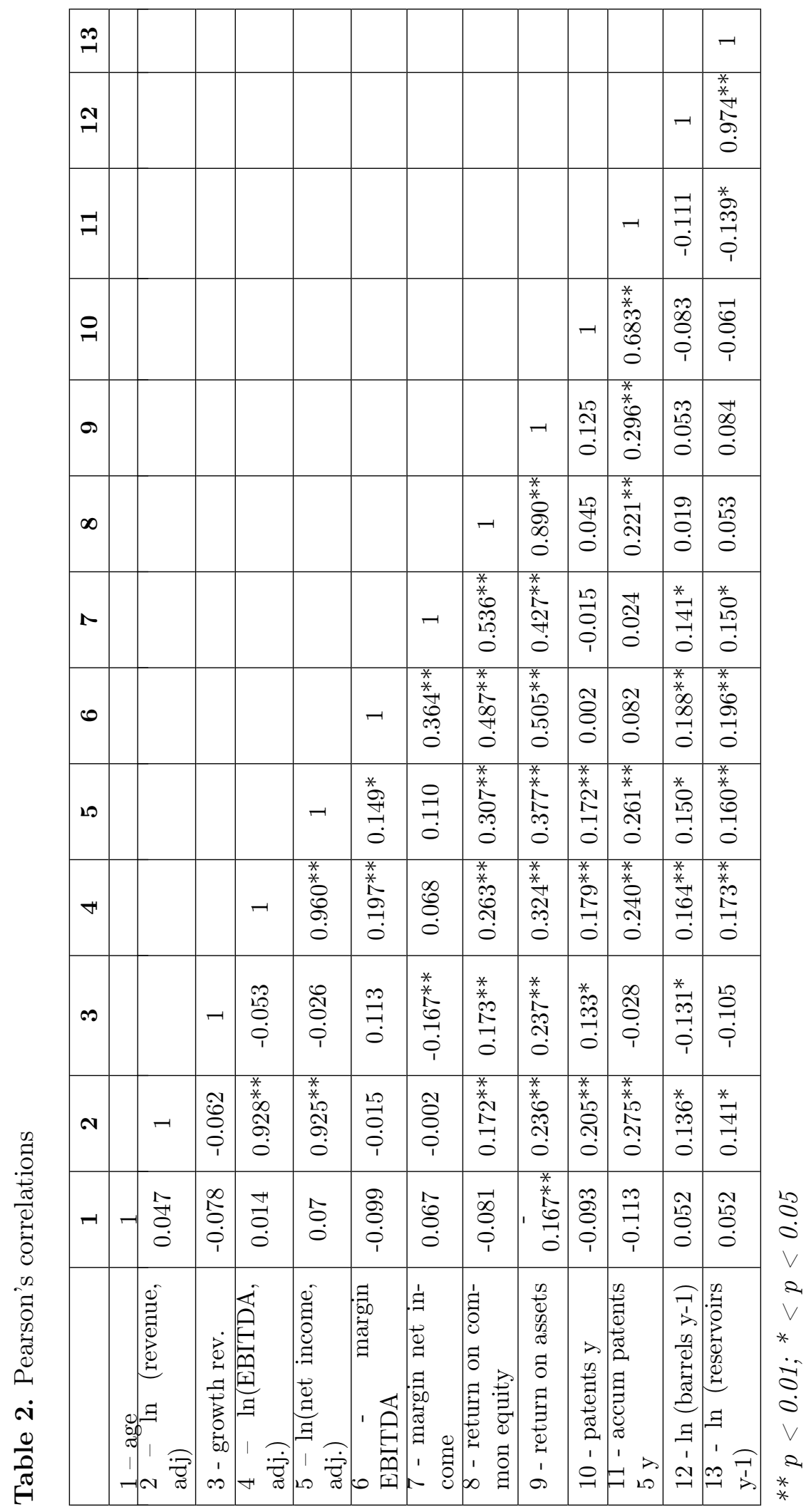


strong correlations (higher than 0.9) among the variables revenue adj., EBITDA adj., and net income adj., and between the variables $\ln$ (barrels y-1) and $\ln$ (reserves $y$-1). This finding is evidence of possible multicollinearity problems. So, before testing the hypotheses, we calculated the variance inflation factor (VIF) of all variables candidates to participate in the model to check for possible multicollinearity problems. According to Hair et al. (2006), a VIF higher than 4.0 indicates that the variable is of an increased risk of causing multicollinearity issues, making it a candidate to be dropped from the model. We made this process several times, dropping the variable with higher VIF, if higher than 4.0, on-by-one. Consequently, $\ln$ (EBITDA, adj.), In (net income, adj.), and return on assets were left out of the model. Not to let ln (barrels y-1) out, we calculated an alternative variable, $\ln$ (barrels $y$-1) residual. It contains the regression residuals with $\ln$ (barrels $y$-1) as the dependent variable and $\ln$ (reserves $y$-1) as the independent variable and captured only the former's variance that cannot be explained by the latter.

As the next step of the analysis, we tested the four models explained in the method section (see the results in Table 3). As can be noticed in Table 3, all models have a good fit (Prob > chi $^{2}<0.05$ ), except for Model 1 of the panel negative binomial. Hypothesis 1, which stated that the greater the proven reserves, the more the firms would be encouraged to apply for patents in Brazil, was supported, as the second regression in both methods showed a positive and significant influence of $\ln$ (reserves $y$-1) on patent application (coefficients of 2.381 in the negative binomial and 14.690 in the Poisson). Hypothesis 2, which stated that firms with higher financial performance would be more encouraged to file patents in Brazil, was partially supported. Considered the four proxies remaining of financial performance, only two (growth rev. and return on common equity) had a positive and significant influence on patent application (coefficients respectively, 0.009 and 0.028 in the negative binomial, and 0.009 and 0.018 in the Poisson). Regarding the control variables, the results of both methods varied intensely. For the reasons already mentioned, the negative binomial results are more reliable. According to it, accumulated patents $5 y$ had a positive influence on patenting (coefficient of 0.011), and ln (Barrels $y$-1) residual had a negative effect (coefficient of -7.029).

\section{Discussion}

From comparing the oil and gas operators with the suppliers, we could observe that the former group applies for more patents per year, with an average of 5.11 compared to 3.03 from the latter but are more than ten times bigger in terms of revenues (see Table 1). Proportionally, the suppliers have more patent applications. It may be because the oil and gas operators more frequently develop process than product innovation (Stadler, 2011), mainly by internal R\&D (Nieto \& Santamaría, 2010) for use in their own upstream operations (Cavalheiro, 2016). Without much access from competitors or suppliers, the risk of copying or other types of misappropriation is lower. In the suppliers' case, they work with their proprietary technologies inside the clients' exploration platforms, which are operating companies. Once a patent protects the technology of a supplier, they could transfer the technology to their clients (Siegel et al., 2004), at the same time mitigating the risk of counterfeiting (Fabry et al., 2006; Joia, 2000; Paula \& Rocha, 2020; Wang et al., 2015) that increases with the constant contact of the clients' employees with their proprietary technologies. The later learn how these technologies work and could copy them by 


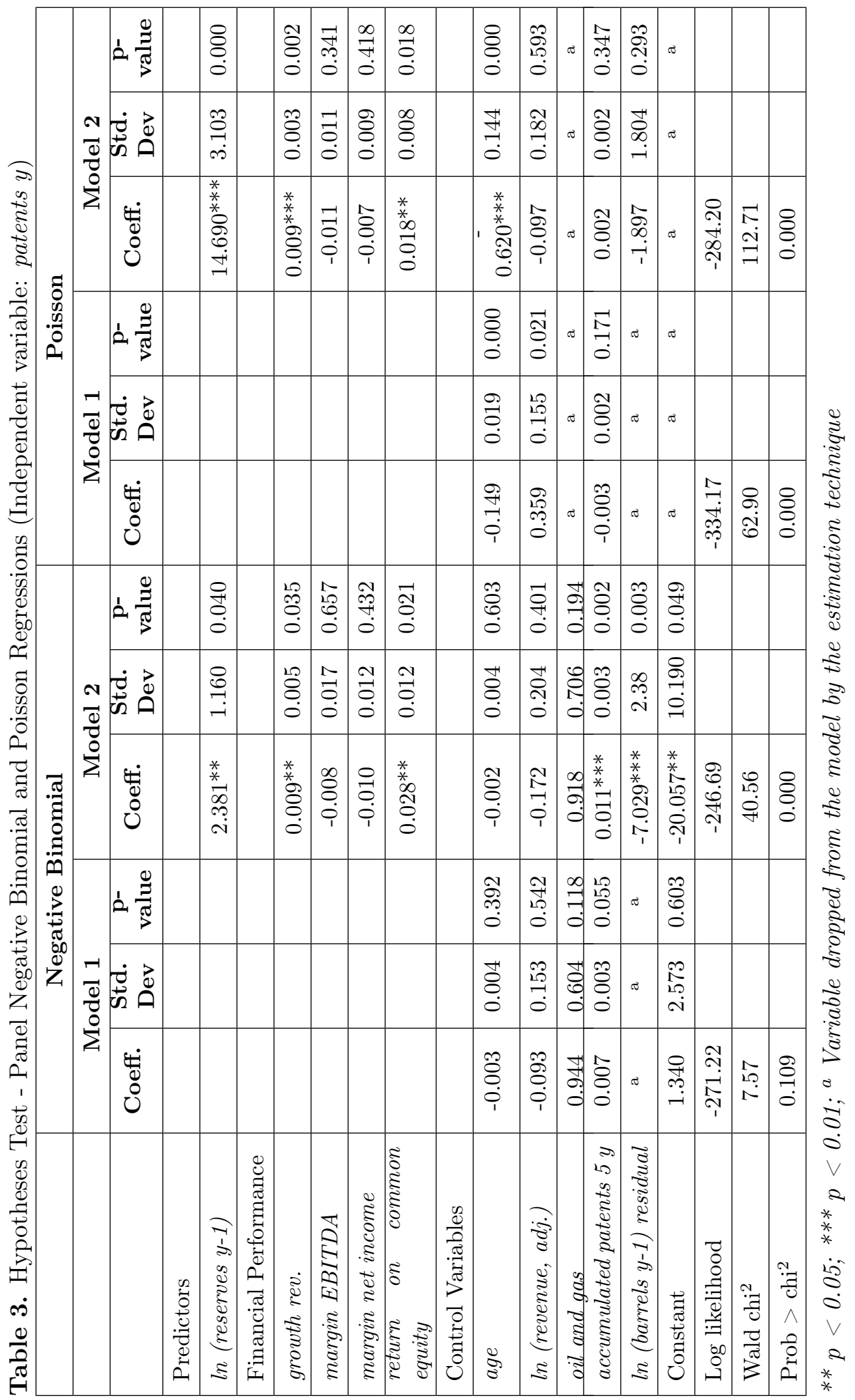


reverse engineering. Suppliers could also be interested in licensing these technologies for their clients (Alt, 2018), which would be facilitated by the patent.

Furthermore, the results indicate the importance of patent applications not only for suppliers or operators but also for all organizations and researchers that conduct applied research in the field. The growth of patent applications from the class E21B after the discovery of pre-salt reserves indicates a growing interest in patenting their technology. Although one of the reasons for patenting is guaranteeing the appropriability of the innovations' benefits by avoiding copying (Bessen \& Meurer, 2007), the oil and gas industry is not among the sectors that suffer more from the threat of this type of misappropriation (OECD/EUIPO, 2016), even with the previously discussed risk for the suppliers. Patents are also less used to protect process than product innovation (Hall \& Sena, 2017), and the upstream operations of the oil and gas industry demand more innovations of the first type, as previously mentioned. Therefore, other motivations should exist for the growing application for patents in Brazil since the discovery of new reserves, as this discovery increased the national market attractiveness (Grandstrand \& Hogersson, 2012; Stadler, 2011), putting the country at a higher level of importance among oil-producer nations. One possibility is the oil and gas industry has high development costs, which increases the impact of misappropriation (Oliveira, 2017). The high costs to develop a technology to be used in the upstream exploration (Wanasinghe et al., 2020) may incentivize the firms to apply for a patent to at least guarantee a future opportunity to prosecute in court another firm that improperly used the patented innovation. Another possibility is that developing technology in the field demands much money invested and technological learning, and by filing a patent application, a firm can demonstrate technical capability in a public way (Freeman, 1982; Huang, 2016; Neuhäusler, 2011), improving its value in the market compared to competitors that do not have many patents of this type (Drivas et al., 2016).

Other interesting findings are related to the hypotheses tested. A positive relationship between the volume of proven reserves and patent applications was found, confirming hypothesis 1 . As only one firm from the sample is Brazilian, the oil and gas multinational Petrobras, and the others are foreign MNEs; this finding indicates a possibility that the interest of these firms to file patents in Brazil is protecting their already owned technologies, which probably were already patented in other countries, predicting future opportunities to use them, a movement analyzed in Stadler (2011). Also, there are some indications that firms with higher performance get more interested in filing patents in Brazil than firms that are financially less successful. This was observed especially considering the financial performance variables growth rev. and return on common equity, which indicated partial support of hypothesis 2 . In contrast, a better position in the financial performance variables margin EBITDA and margin net income did not positively affect a firm's patent application level. It is possible that firms with a more fragile financial position would be more focused on achieving more revenues from their already active oilfields than investing in Brazil, that, even after the pre-salt, is only the 15th country in the world ranking of proven reserves - with 13.0 billion barrels in 2020, far below the leaders Venezuela, with 302.8 billion, and Saudi Arabia, with 267.21billion (US Energy Information Administration, 2020). On the other hand, firms that present an above-average performance would be better positioned to explore new fields in emerging markets such as Brazil, which would increase opportunities for long-term gains (Alley, 2018). 


\section{Conclusion and policy implications}

Brazil became a more important player in the oil and gas industry after the announcement of the discovery of pre-salt in 2007. This paper investigated how the growth of the Brazilian oil reserves, which was strongly influenced by this event, influenced the patenting activity associated with the technical area of E21B (which is the area for patenting innovations developed for the upstream oil and gas industry) in the country by oil and gas operator and supplier MNEs. The investigation relied on data from the 21 firms that applied more for patents in this technical area, comprising 16 suppliers and five oil and gas operators, using panel data from 2001 to 2014 . The study found that although there is a growing tendency for patenting in this area through time, it is strongly related to the growth of proven reserves. However, not all firms had strong incentives to patent their technologies in Brazil because of this growth of proven reserves. Patenting tended to be higher for firms that presented a competitive advantage in the worldwide industry, with a higher financial performance (specifically Growth of Revenues and ROE), which may indicate that only those are positioned to explore a market with growing attractiveness, but which is not one of the most important (as indicated by its $15^{\text {th }}$ position in proven reserves). Firms with a lower performance did not increase their patent applications in Brazil, perhaps because they were focused on improving their level of exploration to increase revenues and reducing costs in their already established markets to gain a competitive advantage in the short-term. As the analyzed MNEs are among the most important firms in the industry and tend to look to Brazil as they look to any other market, these findings may be valid for any country that discovers new oil reserves in such a volume to change its importance as a producer. It also may be useful for countries that make incremental discoveries every year, increasing their total proven reserves smoothly over time.

This study has several limitations. The first limitation is that a patent application in Brazil has 18 months of secrecy, and the Brazilian Patent Office consistently delays publications of patent applications, which makes it impossible to obtain complete patent data less than three years from the patent filing date. This limited us to get trustable patent data only up to 2014, not the most recently filed patents. Besides, a patent application in Brazil usually requires more than ten years to be granted by the Brazilian Patent Office (Júnior, Sobral \& Moreira, 2017). One more limitation is that the study did not consider possible growth of reserves in other countries during the period analyzed, which may have influenced the firms' intention to apply for patents in Brazil, as their resources are limited, and they must choose where to focus their efforts. Moreover, the process of validating proven reserves requires several years, which makes it impossible to fully estimate the total size of the Brazilian pre-salt reserves (Haddad \& Giuberti, 2010). Regarding control variables, we could not get data from the firms' R\&D investments and their number of employees, which are extensively used in the literature. Lastly, we did not consider the effect of Brazilian policies such as local content (O Globo, 2018) and previously existing obligatory participation of Petrobras in the exploration of all pre-salt fields (Deutshe Welle, 2016), which does not exist anymore, but may also have influenced the firms' decision to invest in the country.

Despite these limitations, this paper presents a valuable contribution to understanding the relationship between the growth of proven oil reserves in Brazil, the firms' global performance, and 
patent application. These results may be valid not only for Brazil but also for countries with similar growth of proven reserves in time. The information shown by the analysis may contribute to firms to understand an oil-producer environment, primarily how their competitors and other players are investing in this market by applying for patents. It may also help policymakers to formulate more efficient policies for the sector. For instance, the Brazilian government owns the national oil and gas operator Petrobras, which is responsible for identifying new oilfields. Increasing investments to accelerate this identification could raise the interest of MNEs to invest in the country, creating jobs and generating dividends through taxes applied to oil exploration. As this movement increases interest mainly from high-performing firms, the government could also be safer to open up more its historically closed market to international players as this companies are more financially capable of conducting their operations in the Brazilian soil (and seas).

\section{Acknowledgments}

This work was supported by the National Council for Scientific and Technological Development, CNPq, Brazil [grant number 406559/2018-0] and the Foundation for Research Support of the State of Rio de Janeiro, FAPERJ, Brazil [grant number E-26/210.277/2019(248665)].

\section{References}

Abbas, A., Zhang, L. \& Khan, S.U. (2014). A literature review on the state-of-the-art in patent analysis. World Patent Information, 37, 3-13.

Aharonson, B. S., Baum, J. A., \& Plunket, A. (2008). Inventive and uninventive clusters: The case of Canadian biotechnology. Research Policy, 37(6-7), 1108-1131.

Alley, I. (2018). Oil price and USD-Naira exchange rate crash: can economic diversification save the Naira? Energy Policy, 118, 245-256.

Allison, P. D. (2009). Fixed effects regression models (Vol. 160). SAGE publications.

Alt, P. (2018). Does innovation pay off in terms of firm performance? Evidence from the European automotive industry. MaRBLe, 1 (Research in Business and Economics), 622-634.

ANP (2017). Dados Estatísticos. Accessed 20th December 2017. http://www.anp.gov.br/ dados-estatisticos

Araújo, K. (2014). The emerging field of energy transitions: progress, challenges, and opportunities. Energy Research \& Social Science, 1, 112-121.

Arora, A., Athreye, S., \& Huang, C. (2016). The paradox of openness revisited: Collaborative innovation and patenting by UK innovators. Research Policy, 45(7), 1352-1361.

Bannò, M. (2016). Propensity to patent by family business. Journal of Family Business Strategy, 7, 238-248.

Bell, M., \& Figueiredo, P. N. (2012). Building innovative capabilities in latecomer emerging 
market firms: Some key issues. In E. Amann \& J. Cantwell (Eds.) Innovative firms in emerging market countries. (pp. 24-109). Oxford: Oxford University Press.

Berry, H. (2014). Global integration and innovation: multicountry knowledge generation within MNC s. Strategic Management Journal, 35(6), 869-890.

Bessen, J. \& Meurer, M.J. (2007). What's wrong with the patent system? fuzzy boundaries and the patent tax. First Monday, 12(6).

Blind, K., Cremers, K. \& Mueller, E. (2009). The influence of strategic patenting on companies' patent portfolios. Research Policy, 38, 428-436.

Bloomberg (2018). The Terminal - Bloomberg Professional Services. Accessed 30th January 2018: https://www.bloomberg.com/professional/solution/bloomberg-terminal/?utm_medium= Adwords\&utm_campaign $=$ Trmnl\&utm_source $=$ pdsrch\&utm_content $=$ trmnlsem\&bbgsum $=$ DG-WS-PROFgclid=Cj0KCQjw5-TXBRCHARIsANLixNzi1JyDDl44TAdo003I5BYy43tYBxPQMgsFCssJHhexA41c8Uue6EY wcB.

Boldrin, M. \& Levine, D.K. (2013). The case against patents. Journal of Economic Perspectives, $27(1), 3-22$.

Bolívar-Ramos, M.T. (2017). The relation between R\&D spending and patents: the moderating effect of collaboration networks. Journal of Engineering and Technology Management, 46, 2638.

Bonino, D., Ciaramella, A. \& Corno, F. (2010). Review of the state-of-the-art in patent information and forthcoming evolutions in intelligent patent informatics. World Patent Information, $32,30-38$.

Brandl, K., Darendeli, I., \& Mudambi, R. (2019). Foreign actors and intellectual property protection regulations in developing countries. Journal of International Business Studies, 50(5), 826-846.

Bridge, G., Bouzarovski, S., \& Bradshaw, M. (2013). Geographies of energy transition: space, place and the low-carbon economy. Energy Policy, 53, 331-340.

Bronzini, R., \& Piselli, P. (2016). The impact of R\&D subsidies on firm innovation. Research Policy, 45(2), 442-457.

Brown, S.P.A. \& Huntington, H.G. (2015). Evaluating U.S. oil security and import reliance. Energy Policy, 79, 9-22.

Buchmann, T., \& Kaiser, M. (2019). The effects of R\&D subsidies and network embeddedness on R\&D output: evidence from the German biotech industry. Industry and Innovation, 26(3), 269-294.

Castells, M. (2000). The information age: economy, society and culture. Updated edition, Oxford: Blackwell.

Cavalheiro, G.M.C. (2016). Examining the influence of the pre-salt on patent applications related to drilling fluids in Brazil. Recent Patents on Engineering, 10(1), 3-11.

Cavalheiro, Joia, L.A. \& Gonçalves, A.C. (2014). Strategic patenting in the upstream oil and gas 
industry: assessing the impact of the pre-salt discovery on patent applications in Brazil. World Patent Information, 39, 58-68.

Chatterji, A. K. \& Fabrizio, K. R. (2014). Using users: When does external knowledge enhance corporate product innovation?. Strategic Management Journal, 35(10), 1427-1445.

Cherp, A. \& Jewell, J. (2014). The concept of energy security: beyond the four As. Energy Policy, 75, 415-421.

Choi, Y.M., Cho, D. (2018). A study on the time-dependent changes of the intensities of factors determining patent lifespan from a biological perspective. World Patent Information, 54, 117 .

Clò, S., Florio, M., \& Rentocchini, F. (2020). Firm ownership, quality of government and innovation: Evidence from patenting in the telecommunication industry. Research Policy, 49(5), 103960 .

Coleman, L. (2012). Explaining crude oil prices using fundamental measures. Energy Policy, 40, 318-324.

Cuervo-Cazurra, A., \& Rui, H. (2017). Barriers to absorptive capacity in emerging market firms. Journal of World Business, 52(6), 727-742.

Cyert, R. M., \& March, J. G. (1963). A behavioral theory of the firm. Englewood Cliffs, NJ: Prentice-Hall

Davies, A. (1997). The life cycle of a complex product system'. International Journal Innovation Management, 1, 1192-1216.

Davidson, Russell \& James G. MacKinnon (1989). "Testing for Consistency using Artificial Regressions," Econometric Theory, 363-384.

Deutshe Welle (2016). Mudar regras do pré-sal tem prós e contras para Petrobras. Accessed 4th August 2019: https://www.dw.com/pt-br/mudar-regras-do-pr\%C3\%A9-sal-tem-pr\%C3\% B3s-e-contras-para-petrobras/a-19076064

Drivas, K., Economidou, C., Karamanis, D. \& Zank, A. (2016). Academic patents and technology transfer. Journal of Engineering and Technology Management, 40, 45-63.

Dirnberger, D. (2016). The use of mindmapping software for patent search and management. World Patent Information, 47, 12-20.

Dubaric, E., Giannocaro, D., Bengtsson, R. \& Ackermann, T. (2011). Patent data as indicators of wind power technology development. World Patent Information, 33(2), 144-149.

Ernst, H. (2003). Patent information for strategic technology management. World Patent Information, 25, 233-242.

Ervits, I. (2020). R\&D by US multinationals in China: geography and patterns of co-invention, International Journal of Emerging Markets, ahead-of-print. https://doi.org/10.1108/IJOEM-032019-0171.

Nunes, F., Luna., D. (2017). Pré-sal já compete com Oriente Médio. Accessed: 4th August 2019. https://economia.estadao.com.br/noticias/geral,pre-sal-ja-compete-com-oriente-medio,70002055332. 
EViews (2017). Coefficient diagnosis. Accessed 30th January:

http://www.eviews.com/help/helpintro.html\#page/content/testing-Coefficient_Diagnostics.html

Fabry, B., Ernst, H., Langholz, J. \& Koster, M. (2006). Patent portfolio analysis as a useful tool for identifying R\&D and business opportunities: an empirical application in the nutrition and health industry. World Patent Information, 28, 215-225.

Falce, J. L., Muylder, C. F., Silva, L. O. F., \& Mourão, L. P. (2019). Innovation and Patents: Longitudinal Analysis of Minas Gerais's Indicators. Revista Brasileira de Gestão e Inovação (Brazilian Journal of Management ES Innovation), 6(3), 52-77.

Fraune, C. \& Knodt, M. (2018). Sustainable energy transformations in an age of populism, post-truth politics, and local resistance. Energy Research 83 Social Science, 43, 1-7.

Freeman, C. (1982). The Economics of Industrial Innovation. London: Pinter Publish- ers.

Galini, N.T. (1992). Patent policy and costly imitation. The RAND Journal of Economics, 23(1), 52-63.

Gallini, N. T. (2002). The economics of patents: Lessons from recent US patent reform. Journal of Economic Perspectives, 16(2), 131-154.

Godinho, M.M. \& Ferreira, V. (2012). Analyzing the evidence of an IPR take-off in China and India. Research Policy, 41, 499-511.

Grandstrand, O. \& Hogersson, M. (2012). The anatomy of rise and fall of patenting and propensity to patent: the case of Sweden. International Journal of Intellectual Property Management, 5(2), 169-198.

Greve, H. R. (2003). A behavioral theory of R\&D expenditures and innovations: Evidence from shipbuilding. Academy of Management Journal, 46(6), 685-702.

Haddad, E. \& Giuberti, A.C. (2010). Economic impacts of pre-salt on a regional economy: the case of Espírito Santo. Brazil: Instituto de Pesquisa Economica Aplicada. Perspectivas de desenvolvimento do setor de petroleo e gas no Brasil. Comunicados do IPEA 55.

Hagedoorn, J., \& Wang, N. (2012). Is there complementarity or substitutability between internal and external R\&D strategies?. Research Policy, 41(6), 1072-1083.

Hair, J. F., Black, W. C., Babin, B. J., Anderson, R. E., \& Tatham, R. L. (2006). Multivariate data analysis (Vol. 6). Hall Upper Saddle River: Pearson Prentice.

Hall, B. H., and Sena, V. (2017). Appropriability mechanisms, innovation, and productivity: evidence from the UK. Economics of Innovation and New Technology, 26(1-2), 42-62.

Hausman, J. A. (1978). Specification tests in econometrics. Econometrica: Journal of the Econometric Society, 1251-1271.

Hayashi, S.H.D., Ligero, E.L. \& Schiozer, D.J. (2010). 'Risk mitigation in petroleum field development by modular implantation'. Journal of Petroleum Science and Engineering, 75(1-2), 105-113.

Hu, W., Bao, J. \& Hu, B. (2013). Trend and progress in global oil and gas exploration. Petroleum Exploration and Development, 40(4), 439-443. 
Huang, W.L., Freeney, M.K., Welch, E.W. (2011). Organizational and individual determinants of patent production of academic scientists and engineers in the United States. Science and Public Policy, 38(6), 463-479.

Huang, J.Y. (2016). Patent portfolio analysis of the cloud computing industry. Journal of Engineering and Technology Management, 39, 45-64.

Joia, L.A. (2000). Measuring intangible corporate assets: Linking business strategy with intellectual capital. Journal of Intellectual Capital, 1(1), 68-84.

Júnior, G., Sobral, S., \& Moreira, J. (2017). The Backlog of Patent in Brazil: The Right to Reasonable Duration of the Administrative Procedure. Revista Direito GV, 13(1), 171-203.

Karvonen, M., Klemola, K. (2019). Identifying bioethanol technology generations from the patent data. World Patent Information, 57, 25-34.

Kalcheva, I., McLemore, P., \& Pant, S. (2018). Innovation: The interplay between demand-side shock and supply-side environment. Research Policy, 47(2), 440-461.

Katila, R., \& Ahuja, G. (2002). Something old, something new: A longitudinal study of search behavior and new product introduction. Academy of Management Journal, 45(6), 11831194.

Kim, L. (1997). Imitation to innovation: The dynamics of Korea's technological learning. Cambridge: Harvard Business Press.

Kim, L. (1998). Crisis construction and organizational learning: Capability building in catching-up at Hyundai Motor. Organization Science, 9(4), 506-521.

Lall, S. (2003). Indicators of the relative importance of IPRs in developing countries. Research Policy, 32(9), 1657-1680.

Lang, J.C. (2001). Management of intellectual property rights: Strategic patenting. Journal of Intellectual Capital, 2(1), 8-26.

Lema, R., Quadros, R., \& Schmitz, H. (2015). Reorganising global value chains and building innovation capabilities in Brazil and India. Research Policy, 44(7), 1376-1386.

Levinthal, D., \& March, J. G. (1981). A model of adaptive organizational search. Journal of Economic Behavior 83 Organization, 2(4), 307-333.

Lin, C., Wu, Y. J., Chang, C., Wang, W., \& Lee, C. Y. (2012). The alliance innovation performance of R\&D alliances - the absorptive capacity perspective. Technovation, 32(5), 282292.

Lu, D.D.; Zeng, P. \& Lan, H. (2018). Co-patent, financing constraints, and innovation in SMEs: an empirical analysis using market value panel data of listed firms. Journal of Engineering and Technology Management, 48, 15-27.

Macrotrends (2019). WTI Crude Oil Prices - 10 Year Daily Chart. Accessed 4th August 2019: https://www.macrotrends.net/2516/wti-crude-oil-prices-10-year-daily-chart.

Mendes, P.A.S., Hall, J., Matos, S. \& Silvestre, B. (2014). Reforming Brazil's offshore oil and gas 
safety regulatory framework: lessons from Norway, the United Kingdom and the United States. Energy Policy, 74, 443-453.

Miaou, S. P. (1994). The relationship between truck accidents and geometric design of road sections: Poisson versus negative binomial regressions. Accident Analysis $\&$ Prevention, 26(4), 471-482.

Mouritsen, J. \& Koleva, G. (2005). Packing and unpacking knowledge: patents and intellectual capital. Journal of Intellectual Capital, 6(3), 308-321.

Moutinho, R., Au-Yong-Oliveira, M., Coelho, A., \& Pires Manso, J. (2015). The role of regional innovation systems (RIS) in translating R\&D investments into economic and employment growth. Journal of Technology Management \& Innovation, 10(2), 9-23.

National Petroleum Council (2007). Oil and gas technology development. Topic paper \#26, National Petroleum Council Global Oil \& Gas study. Accessed 4th June 2019. http://downloadcenter. connectlive.com/events/npc071807/pdf-downloads/Study_Topic_Papers/26-TTG-OGTechDevelopment. pdf

Nelson, R.R. (2007). The changing institutional requirements for technological and economic catch up. International Journal of Technological Learning, Innovation and Development, 1(1), $4-12$.

Neuhäusler, P., Frietsch, R., Schubert, T., \& Blind, K. (2011). Patents and the financial performance of firms-An analysis based on stock market data (No. 28). Fraunhofer ISI discussion papers innovation systems and policy analysis.

Nguyen, A.L.T. (2020), FDI inflows and intellectual property rights for MNEs in emerging markets: an alternative approach through the lens of trademarks in Vietnam (1986-2016), Multinational Business Review, ahead-of-print. https://doi.org/10.1108/MBR-10-2019-0140

Nieto, M. J. \& Santamaría, L. (2010). Technological collaboration: Bridging the innovation gap between small and large firms. Journal of Small Business Management, 48(1), 44-69.

O Globo (2018). Entenda o que é conteúdo local no setor de petróleo. Accessed 2nd December 2018: https://oglobo.globo.com/economia/entenda-que-conteudo-local-no-setor-de-petroleo-20889716.

OECD/EUIPO (2016). Trade in counterfeit and pirated goods: mapping the economic impact. OECD Publishing, Paris

Oliveira, R. (2011). Dealing with plenty: Brazil in the era of surplus oil. Master Thesis. University of Illinois.

Operti, E., \& Carnabuci, G. (2014). Public knowledge, private gain: The effect of spillover networks on firms' innovative performance. Journal of Management, 40(4), 1042-1074.

Pargaonkar YR. (2016). Leveraging patent landscape analysis and IP competitive intelligence for competitive advantage. World Patent Information, 45, 10-20.

Park, B. J. R., Srivastava, M. K., \& Gnyawali, D. R. (2014). Walking the tight rope of coopetition: Impact of competition and cooperation intensities and balance on firm innovation performance. Industrial Marketing Management, 43(2), 210-221. 
Paula, F. O., \& Barboza, T. S. (2018). An Empirical Study of Process Innovation in an R\&D Laboratory of an Oil \& Gas Company. Revista Gestão em Análise, 7(1), 44-59.

Paula, F. D. O., \& Silva Rocha, R. J. (2020). The Effect of R\&D Investments and Patents on the Financial Performance of Latin American Firms. Latin American Business Review, 1-20.

Paula, F. D. O., \& Silva, J. F. D. (2018). The impact of alliances and internal R\&D on the firm's innovation and financial performance. BBR. Brazilian Business Review, 15(6), 533-550.

Pavitt, K. (2005). Innovation Process. In Fagerberg, J., Mowery, David C. \& Nelson, Richard $\mathrm{R}$ (Orgs.). The Oxford Handbook of Innovation. New York, Oxford University Press.

Picard, P.M. \& van Pottelsberghe, B. (2011). Patent office governance and patent system quality. Center for Research in Economic Analysis, Discussion Paper 2011-06.

Qi, M., Wang, Y., Zhang, M. Y., \& Zhu, H. (2014). The evolution of R\&D capability in multinational corporations in emerging markets: evidence from China. International Journal of Technology Management, 64(2-4), 210-231.

Rodriguez, M.B. \& Suslick, S.B. (2009). An overview of Brazilian petroleum exploration lease auctions. \&(1), 6-20.

Rydehell, H., Isaksson, A., \& Löfsten, H. (2019). Business networks and localization effects for new Swedish technology-based firms' innovation performance. The Journal of Technology Transfer, 44 (5), 1547-1576.

Salter, A. \& Sobrero, M. (2013). Academic engagement and commercialisation: A review of the literature on university-industry relations. Research Policy, 42, 423-442.

Shafiee, S. \& Topal, E. (2009). When will fossil fuel reserves be diminished? Energy Policy, 37(1), 181-189.

Scherer, F.M. (1972). Nordhaus' theory of optimal patent life: a geometric reinterpretation. American Economic Review, 62(3), 422-427.

Schilling, M. A., \& Phelps, C. C. (2007). Interfirm collaboration networks: The impact of large-scale network structure on firm innovation. Management Science, 53(7), 1113-1126.

Schilling, M. A. (2015). Technology shocks, technological collaboration, and innovation outcomes. Organization Science, 26(3), 668-686.

Schneider, C. (2007). The determinants of patent applications outcomes - does experience matter? MPRA Paper No. 3359, Copenhagen Business School.

Siegel D. S., Waldman D. A., Atwater L. E., \& Link A. N. (2004). Toward a model of the effective transfer of scientific knowledge from academicians to practitioners: Qualitative evidence from the comercialization of university technologies. Journal of Engineering and Technology Management, $21(1-2), 115-142$.

Sovacool, B.J. (2016). How long will it take? conceptualizing the temporal dynamics of energy transitions. Energy Research \&5 Social Science, 13, 202-215.

Stadler, C. (2011). Process innovation and integration in process-oriented settings: The case of the oil industry. Journal of Product Innovation Management, 28(s1), 44-62. 
Su, H.N. \& Lin, Y.S. (2018). How do patent-based measures inform product commercialization? - the case of the United States pharmaceutical industry. Journal of Engineering and Technology Management, 50, 24-38.

Trojbicz, B., and Loureiro, M.R. (2018). Brazilian oil sector reforms: the role of technical know-how and corporate ethos in Petrobras's dominance. Energy Policy, 118, 588-595.

U.S. Energy Information Administration (2020). International Energy Statistics, crude oil including lease condensate. Retrieved from: https://www.eia.gov/international/data/world $\# /$ ?tl type $=$ p\&tl_id $=5$-A\&pa $=000000000000000000008 \& c t=0 \&$ ord $=S A \& c=$ ruvvvvvfvtvnvv1urvvvvfvvvvvvfvvvou $\mathrm{f}=\mathrm{A}$..

Wang, M.Y., Lo, H.C. \& Liao, Y.Y. (2015). Knowledge flow determinants of patent value: evidence from Taiwan and South Korea biotechnology patents. International Journal of Innovation and Technology Management, 12(3).

Wanasinghe, T. R., Gosine, R. G., James, L. A., Mann, G. K., de Silva, O., \& Warrian, P. J. (2020). The Internet of Things in the Oil and Gas Industry: A Systematic Review. IEEE Internet of Things Journal, 7(9), 8654-8673.

Wenrui, H., Jingwei, B., \& Bin, H. (2013). Trend and progress in global oil and gas exploration. Petroleum Exploration and Development, 40(4), 439-443.

WIPO (2018a). Patentscope. Accessed 2nd December 2018: https://patentscope.wipo.int/

WIPO (2018b). E. Fixed Constructions. Accessed 2nd December 2018. http://www.wipo.int/ classifications/ipc/en/ITsupport/Version20170101/transformations/ipc/20170101/en/htm/E21B. htm.

Hu, Y., Wood, J. F., Smith, V., \& Westbrook, N. (2004). Friendships through IM: Examining the relationship between instant messaging and intimacy. Journal of Computer-Mediated Communication, 10(1), 38-48.

World Bank (2019). World Bank open data. Accessed 20th January 2019: https://data. worldbank.org

Yayavaram, S., \& Chen, W. R. (2015). Changes in firm knowledge couplings and firm innovation performance: The moderating role of technological complexity. Strategic Management Journal, 36(3), 377-396.

Xu, S., Fenik, A. P., \& Shaner, M. B. (2014). Multilateral alliances and innovation output: The importance of equity and technological scope. Journal of Business Research, 67(11), 24032410. 


\section{Biographies}

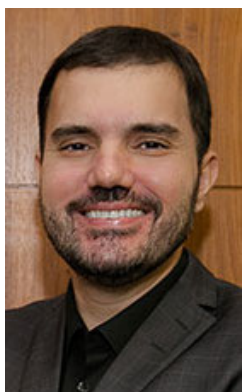

Fábio O. Paula. Dr Fábio de Oliveira Paula is Assistant Professor of Strategy at the IAG Business School, Pontifical Catholic University of Rio de Janeiro (PUC-Rio). Ph.D. in Business Administration at PUC-Rio, in the research field of Strategy (2017). M.Sc. in Business Administration at PUC-Rio (2006). Graduated in Computer Engineering at the same university (2001). Conducts research and has articles published in international academic journals of high impact and presented at international conferences in the fields of Innovation Management and Strategy. Has professional experience in several industries such as retail, foreign trade, marketing, education, information technology and oil and gas.

CRediT Statement: Conceptualization, Data curation, Formal analysis, Methodology, Visualization, Writing - original draft, Writing - review \& editing

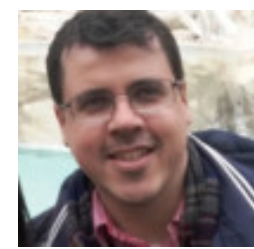

Gabriel M. Cavalheiro. PhD in Business Administration from FGV / EBAPE, received the M.S. and B.S. degree in Production Engineering from Delft University of Technology (TU Delft). Adjunct Professor at the Department of Entrepreneurship and Management, Faculty of Administration and Accounting Sciences, Universidade Federal Fluminense (UFF). He has experience as a Patent Examiner at the National Institute of Industrial Property (INPI), Professor of Technological Graduation at FGV / EBAPE, Academic Consultant at UniLaSalleRJ, IT Auditor at EY Netherlands, Visiting Researcher at Georgia State University, as well as experience in companies in the areas of innovation, IT, risk management and business analysis. He has research interest in the areas of: Information Systems, Entrepreneurship, Innovation and Intellectual Property.

CRediT Statement: Validation, Visualization, Writing - original draft, Writing - review \& editing 